Dispossessing Animism: Zong! and Spiritual Baptism

Philip Dickinson

\begin{abstract}
This essay intervenes in the emerging discussions around animism by situating animism within the ongoing projects of colonial bio- and necropolitics. While 'animism' is often taken to denote pre- or anti- or counter-modern cosmologies that promise an alternative to the ontologies that sustain colonial violence, it has been recognised that there are in fact a variety of ways in which animism is 'built in' to modernity, and in which modernity itself is constituted as animistic. This essay pulls this recognition in a new direction by developing a theory of the 'distribution of the animate', describing a system of animist perception and expression by which different kinds of bodies, beings and forces are positioned and differentiated. This theory allows me to explore a shared zone in which the apparently relentless materialism of colonial biopolitics and the supposedly spiritual orientation of animism meet, collide and intertwine. This zone appears in this essay in a range of moments and modes, including the 'word' of possession in new world conquest, the anthropological invention of animism itself, the anticolonial resistance and spirit possession of the Hauka, the transubstantiative magic of chattelisation and, via an extended close reading, the text and performance of Marlene NourbeSe Philip's long poem, Zong!. I show that animism is not really the other to colonial modernity: to say this is to buy into a foundational colonial myth. Instead, what is at stake in the theoretical construct of animism are the qualities that distinguish one kind of life from another. The colonial systems for knowing the other (enshrined in anthropology) and dominating the other (exemplified by biopolitics) invent, recruit and disavow animism in order to naturalise the denial of personhood to colonialism's others. My ultimate argument is that for animism to escape these systems of possession it has to become something other than animism, by affirming a dispossession (rather than distribution) of animacy. I locate this dispossession in the sound and performance of Zong! and associate it with the poem's refusal of more familiar literary projects that try to reclaim and restore voice and personhood.
\end{abstract}

\title{
Keywords
}

animism, dispossession, biopolitics, sound, nourbese Philip, personhood 


\section{Dispossessing Animism: Zong! and Spiritual Baptism}

There is an extraordinary power in the possession of a language.

- Frantz Fanon, Black Skin, White Masks

Words break into sound, return to their initial and originary phonic sound - grunts, plosives, labials - is this, perhaps, how language might have sounded at the beginning of time?

- M. NourbeSe Philip, 'Notanda' to Zong!

This essay attempts to situate animism within the terrain of colonial biopolitics. The aim is to tease out a relationship between the supposedly nonmodern practice of animism and the paradigmatically modern work of making live and letting die, or between the notionally precolonial cosmologies of the animists and the definitively colonial project of making die, of necropolitics. ${ }^{1}$ I want to give these apparently distinct and even incompatible terms a jolt, not to breathe new life into them but to expose their shared investments in the processes of making (a)live.

If it is possible to speak of an animist turn in contemporary thought, one can further distinguish between ontological thinkers of animism, such as Eduardo Viveiros de Castro, Eduardo Kohn and Tim Ingold, and epistemological thinkers, such as Nurit Bird-David and Graham Harvey. Whether animism is interpreted through ontology or epistemology, as a framework of being or as a way of knowing, it tends to constitute an alternative to the deficiencies of modern thought in its dominant and dominative forms. Bird-David, for example, pursues animism as a 'relational epistemology' that provides a corrective to the dualism of 'modernist' thought, ${ }^{2}$ while for Harvey animism incubates an ethics of environmental and interpersonal 'respect'. ${ }^{3}$ For Ingold, animism names an 'animic' ontology rather than epistemology: it is not about belief in an ensouled world or the imputation of spirit to inert matter, because the animacy of the world is understood to be 'ontologically prior' to the differentiation between spirit and substance, agency and materiality. Animism here is about being in rather than holding beliefs about the world. ${ }^{4}$ Viveiros de Castro's work on Amazonian perspectivism pursues an extravagant theoretical reversal, as he advocates the necessity of an 'externalisation of reason' rooted not in non- or pre- but in counter-modern thought: this is not about 'classifying cosmologies' but 'counter-analyzing [our] anthropologies'.5 
In contrast to these trends, I want to read animism as something that already inheres in modernity - and modernity as something that inheres in animism. This is not in itself an entirely original move: the supposed opposition between modernity and animism, or secular reason and myth or magic, has been challenged from a variety of perspectives. ${ }^{6}$ But my focus is different. If ontology is about how the world is, and epistemology about how the world is known, my interest is in how the world is produced, through power. In bringing animism into the orbit of the biopolitical, I therefore shift the focus from the prior animacy of things or the ways by which we might become attuned to their aliveness, to the sense in which animacy, or in more heavily freighted vocabulary 'life', is produced and managed by power. I explore the entanglement of colonial power with animism over the question of who and what is living and who or what is dead, of where to locate the bodies of this world within a differentiated universe of aliveness and a hierarchised system of personhood. Here I develop the concept of the 'distribution of the animate'. This phrase indicates that animacy — encompassing full human personhood and the most minimally alive - is something that is not only described but also distributed, involving the assignation of particular 'parts and positions' within an animistic hierarchy to different beings, bodies and forces.

If biopolitics implies the distinctly animistic labour of distributing personhood, aliveness or animacy, it also generates new bodies and locii for biopolitical capture. Biopolitics, ironically, is always extending its sense of what it means to be alive. It therefore seems unlikely that animism would promise a ready-made exit from the putatively de-animative dynamics of modernity. In contrast to the gesture of reclaiming animism from the abjection to which colonial anthropologists consigned it, or revitalising it in response to the predicament of the Anthropocene, I am interpreting animism less as a viable term for a non-modern ontological disposition than as a feature common to modern thought and its disavowed others, in the simple sense that these systems always imply a work of animation and de-animation. This involves some account of the divisions between and within the living and non-living and some system (cultural, political, ritual) for reproducing them.

It is clear that animism as a theoretical construct is already bound up with colonial history, as can be seen in the colonial anthropology of figures such as Edward B Tylor. My further and more original claim is that colonialism is a kind of animism that operates in part through the very invention of animism as a concept, by which coloniality sought to establish its own rationalist supremacy. To summarise briefly: colonial anthropologists thought that animists 
were mistaken because they attributed human qualities - personhood, thought, aliveness, agency - to nonhuman beings and forces. This 'mistake' informed the colonial decision to deny these purportedly human qualities to animists themselves. Animists fail to separate themselves from the mute, nonhuman world that it is the precise mission of colonialism to dominate. What is at stake in animism, re-read through colonial power, is not the affirmation of the potential liveliness of all things, but the profoundly political and biopolitical question of who and what gets attributed human qualities and who and what doesn't. Coloniality functions as animism in asking and answering this question, even as it disavows this animism by presenting itself as Enlightenment - as something that sees the world as it is, rather than as something that creates and distributes its hierarchies and divisions. This political question is rarely if ever addressed by new animism and its cognates. Colonial reason, moreover, reread through animism, doesn't secure a special place for human beings as endowed with a higher life but only the supremacy of a particular kind of human: the white man.

Where does this leave animism 'itself', if it is possible to speak of such a thing? I am interested throughout this essay in how colonial animism may be resisted, subverted, shortcircuited, and escaped. And I am interested in how animist practices are put to work in this process. This means that, having degraded the opposition between modernity/coloniality and animism I will, in turn, suggest some ways in which animism can and does resist. I find one answer in Michael Taussig, who explores the anticolonial energy of animist practices that redeploy signifiers of colonial power and redistribute the hierarchies of animacy, at least in the space-time of performance. To dispossess animism, however - to reference my title - is to take a further step: to dispossess it of this animating and de-animative capacity. Or might it be that animism itself can somehow accomplish this dispossession? Can we think, as I hope to show, of an animism that would dispossess itself?

The promise of animism as (bio)politicised performance resides, I suggest, in this dispossessive power. I develop my argument through a reading of Zong! (2008), the remarkable long poem by the Tobagonian-Canadian poet, M. NourbeSe Philip. The poem exposes the animistic underpinnings of coloniality; it estranges and unworks colonial animism, through a playfully animistic deployment of language; and it re-activates a nontotalising and self-aware animism that is open to history and historical action, through a partial and strategic appropriation of the syncretic animism of Spiritual Baptist religious performance. What is crucial is that the poem ultimately seeks to free animacy from the 
distributive power of system itself, as it undoes the differentiations and hierarchies of colonial animism and refuses more familiar literary projects of re-personalisation. Here I focus upon Philip's insistence on sound as the material affirmation of an animacy from the void, from 'the beginning of time'. This animacy is heard beyond (or before) the biopolitical dispensations of modern personhood, and must be heard as the precondition for a newly emancipated or dispossessed voice.

\section{Distribution of the Animate}

It is usually assumed that the advent of colonial modernity heralded the extinction of animism. It is commonplace within postcolonial theory, for example, to position European colonialism as a force that overwrites or obliterates animist and other indigenous cosmologies, replacing them with a homogenising regime of countability, measurement, reduction, and extraction. ${ }^{7}$ Colonial anthropologists, interestingly, thought something similar, or rather invented the historical schema that shapes this perception: Edward B Tylor (one of the first to use the term 'animism' in a systematic way), or Lucien Lévy-Bruhl in the French imperial context, argued in their respective idioms that the rational ontology of European rule inevitably superseded 'savage' thought. ${ }^{8}$ These interpretations, however, tend to collapse the history of the violent destruction of animist ontologies into the elimination of animacy itself, as if the subjugation of colonised peoples also secured the supremacy of instrumental reason and its deanimated world. In this view, colonial modernity appears as a force for disenchanting the world. As Adorno and Horkheimer put it, 'the dis-enchantment of the world is the extirpation of animism' (my emphasis). ${ }^{9}$

My first step is to suggest something different. Rather than pitting Enlightenment and animism against one another in a dialectical struggle, I want to reformulate the relationship between coloniality and animism through the concept of the 'distribution of the animate'. I am adapting this phrase from Jacques Rancière's familiar idea of the 'distribution of the sensible', which refers to the sociopolitical rules that determine what can be 'apprehended by the senses'. The distribution of the sensible implies a system of sense perception, involving procedures of inclusion and exclusion that separate the visible from the invisible, the audible from the inaudible, regulating what can be 'said, thought, made, or done'. ${ }^{10}$ The distribution of the animate, by analogy, is then a system of animist perception and expression, within 
which different kinds of bodies, beings and forces are positioned. These 'parts and positions' are not passively given: the system reproduces them even if they are assumed to be selfevident. This is not a belief system but a much larger machine with a more extensive contextual scaffolding, involving such things as technology, ritual, language, social life, and political power.

The anthropological invention of animism involved separating the distanced European outlook of the detached observer, emerging out of the division between object and subject and the supposed sovereignty of reason, from an animistic belief in an ensouled world, in widely distributed personhood, and in the immediative powers of ritual and language. ${ }^{11}$ One might sharpen the distinctions here: animism is about interaction with a living world; modernity names the domination of a deanimated nature. Or: animism is mistaken; modern science captures objective reality. But one might also try to blunt them: aren't we distinguishing one version of how animacy is distributed in the world from another, rather than separating an animated world from a de-animated one?

Bruno Latour declares that we have never been modern. For him, it is less puzzling in our epoch that 'people still believe in animism' than that others believe naively in a 'deanimated world of mere stuff', given the terrifying intensification of non-human agencies in the Anthropocene. ${ }^{12}$ But this effort to unseat the modernity/animism opposition needs to follow different lines. After all, animist cosmologies do not assert that everything is equally alive, nor that the world is defined by the intensification or proliferation of agencies. As Irving Hallowell's celebrated work on Ojibwe thought demonstrates, to imagine a many-personed world is not to assume the 'human-likeness' or 'life-likeness' of inanimate things. The category of personhood is internally differentiated, so that there may be human persons, rock persons, bear persons, and so on. ${ }^{13}$ Moreover, the work of de-animation can certainly play a role within animist thought. Viveiros de Castro makes this clear in his work on the metaphysics of predation. Perspectivism 'is only rarely applied to all animals' (even though it includes the dead). It most frequently involves large predators and scavengers (jaguars, anacondas, vultures) and the typical prey of humans (wild boar, monkeys, fish). Nevertheless, most if not all things that exist are defined by their 'relative position on a scale of predatory power'. ${ }^{14}$ Amazonian perspectivism is, among many other things, a thought of 
differentiations and hierarchies, subjectivisations and de-animations.

To step back to the general, animism essentially names one system for distributing animacy (whether this is considered to mean personhood or just aliveness), which is taken to be different from modernity's (de)animative systems. This is where new materialism and animism, as related counterpoints to modern regimes of thought, sharply diverge: while new materialism, including the work of Latour and others such as Jane Bennett, seeks to amplify the agency of nonhuman things, where this agency is imagined in the least restrictive terms possible, animism asserts the existence of various forms of nonhuman personhood or minimally personed aliveness, systematically articulated within a total vision of being. New materialism has no interest in personhood: it is on the contrary invested in uncovering forms of agency and animation immanent to matter, without reference to supposedly anthropocentric ideas of agent, subject and person. ${ }^{15}$ These forms of agency emerge through a heightened perceptual sensitivity which suspends habitual ideas about what is alive and what is dead. It is not about a new distribution of the animate, in other words, since it by definition refuses to re-assign 'parts and positions'; it is more a happy corrective to modern perceptual biases — and one with uncertain political implications. ${ }^{16}$

\section{Animist Coloniality}

If new materialism advocates a loosely animist ethos in the service of the post-humanist renewal of modern thought, then it needs to be recognised that modernity is already an articulation (or reterritorialization) of animism as a distributive system. This is most obvious in the case of biopolitics, since biopolitics literally takes 'life itself' as its object of control. But the case of animism and colonial modernity makes this recognition more complicated, since animism is originally an invention of colonial discourse. The animism of coloniality is therefore bound up with the dynamics of disavowal. Colonial modernity has disavowed the animism that is in fact proper to it.

I do not interpret this disavowed animism as a residual expression of the vibrancy of matter, but as linked to the appropriation of the power to distribute the animate, to animate and to deanimate the bodies of this world. This is to approach the exertion of a power over the spheres of the living and the dead. What is striking is that this power was exercised in a particularly violent way at the scene of animism's anthropological invention: in the colonial encounter. It 
is as if, in order to move beyond animism into the world of (eventually) secular and scientific rationality, modernity needed to recruit, retain or intensify animism as a power over life or death, while disavowing this move through the violent othering of animism and animists. This is connected to the history of the possession of colonised lands and bodies. Colonial or biopolitical animism is an animism that expresses a material and spiritual dispossession.

I am here echoing Laurent Dubreuil's effort to '[situate] the colony in relation to possession' in his book Empire of Language. Dubreuil's reading of French imperialism revolves around what he calls the 'word' of possession. The original word for colony in French was possession, and for this reason there is a sense in which the performative power of the colonial speech-act — by which territory was legally appropriated — also 'communicates with' indigenous spirit possession. ${ }^{17}$ In essence, Dubreuil claims that the language of a figure like Champlain is defined by a special kind of speech act that borrows the animistic power that it simultaneously disavows. Champlain 'speaks to change reality'; what is interesting is that this mode of transformative speech appropriates a spiritual power associated with newly dispossessed indigenous people. Champlain appropriates indigenous peoples' lands and the powers of possession that reside (according to colonial anthropologists) in their spiritual practices.

Dubreuil's reading seems something of a provocation. Does the fact that Champlain uses the word 'possession' necessarily invoke indigenous spirit possession? Is this confusion or semantic co-implication really there in Champlain's words (and in the words of many others that Dubreuil quotes), or is this merely an effect of Dubreuil's reading? The fundamental insight, that colonial speech involves a certain phrase of possession that is far from merely legal or rational, seems intuitively right. It plainly follows that Champlain speaks to change reality. But what theory of language, or of the speech act, is at play in this claim? While Dubreuil remains elusive on these matters, we might venture that his whole argument implies an animistic operation of language. Christopher Bracken, in a book that similarly moves between colonial and postcolonial archives, explains how animism was distinguished from modern or civilised thought by its obedience to what Lévy-Bruhl called the 'law of participation', as opposed to the 'law of contradiction'. ${ }^{18}$ The law of participation implies a particular conception of what discourse or language is and does: rather than describing the world, it participates in it; rather than representing or mediating things, it is about 
actualisation, 'immediation'. Throughout the nineteenth and early twentieth-century colonial and anthropological archive (and earlier, if Dubreuil is to be believed), one encounters the constant unhinging of the distinction between 'mimesis, a discourse that imitates, and poiesis, a discourse that invents'. ${ }^{19}$ We find what Agamben would call an 'intimate caesura', constantly retraced, between a language that steps back from the world in order to represent it as an object, and a language that immediates, enacts, invents the world. ${ }^{20}$ But the intimacy of this caesura rests upon the fact that it cuts within modern thought, so that the separation between the two sides is unstable. Discourse, in this animistic mode, becomes something else: it is 'not an instrument for the communication of thought but an occasion for the deployment of forces'. ${ }^{21}$

How does this distinction between a language of participation and contradiction relate to animism understood as a distributive system? To distribute animacy is to enact a power, a force; it is to perform an involvement in the world, rather than to describe a world whose parts and positions are determined in advance. ${ }^{22}$ Modern thought claims a certain detachment from the world; it reserves no space for magic or for the shamanistic because its purpose is not to transform or intervene but only to represent. ${ }^{23}$ This anthropological self-description, though, is clearly faulty: the entire domain of modern biopolitics is devoted precisely to intervention in the domain of the living, indeed to the invention of new bodies and horizons of aliveness to be encompassed by sovereign control. Furthermore, if disenchantment is the extirpation of animism, the very force of that 'is' implies an animistic or magical operation of language, one that licenses in turn the bloody magic by which people are turned into things. I will return to this point in my close reading of the estrangement of the copula in Philip's Zong! below, but for now I need to recognise that animism, in turn, may confront this colonial distribution of animacy through a minoritarian incursion that dispels or reworks it. Both animistic modes are about power, but the former is about a dominative potestas and the latter a potentially historically liberating potentia.

The so-called 'new animism' risks offering a simple cultural correlative to the project of new materialism: Graham Harvey's advocacy of 'respect for the living world' implies an ethical posture that recognises our shared investment in a horizontal network of relations that enmeshes different kinds of bodies. These forms of respect are to be found in a variety of cultural and subcultural locations that offer coherent alternatives to the dominative modes of 
knowing and being. But the conception of animism I am pursuing, evident in the work of Dubreuil and Bracken, is all about relations of power. This is evident, first of all, in the status of animism as an operative signifier within the colonial division of the world, bound to the violence of modernity's conceptual and material autoconstitution. The very concept of animism was created within a racialised process of onto-epistemological division, in which the insistence upon one kind of difference encoded a further series of hierarchical and historically durable oppositions. In essence, animism belonged to an obsolete past whose residual traces were savage peoples, and it was the project of colonial power to bind these peoples to its own temporality: to colonise them. ${ }^{24}$ But, as Michael Taussig shows in Mimesis and Alterity, animism may be about power in another sense, insofar as it deploys a potentially insurrectionary agency via its shamanistic and mimetic devices.

One of Taussig's examples is the Hauka movement, whose members were imprisoned by the French in Niger and the British in Ghana in the 1920s and 30s. The Hauka had amassed significant political power, establishing their own settlements and networks of anticolonial influence. They were openly dissident, threatening the legitimacy of the colonial order. The movement began among the Songhay people, who would dance, dress up and mimic colonial officials, becoming possessed by their spirits. In these states of possession they would acquire strange powers and exhibit disturbing bodily effects: 'frothing at the mouth, bulging of the eyes, contorted limb movements, inability to feel pain'. ${ }^{25}$ The Songhay would mimic specific white men, who would then enter the Hauka pantheon, such as Korsasi, the wicked major, who was the spirit of a French commandant who brutally assaulted early members of the movement, or King Zuzi, the colonial chief justice. ${ }^{26}$ Taussig links the Hauka to the 'African white man' photographed by Herbert Cole in an Igbo Mbari shrine house in 1967. He speculates that the coloniser might greet this representation with a self-congratulatory response: 'They think we are gods'. But he argues that there is something excessive about this sculpture that ought to trouble this complacency: 'After all, who knows - in imaging us as gods, might they not take our power?' 27 This imagines a reversal of the process of 'possession' described by Dubreuil: here, it is anticolonial mimesis - the Hauka or Igbo 'possession' of the form of the coloniser - that threatens the European 'possession' of African lands. It does so in a material way: Hauka spirit possession is partially interpretable as a pragmatic tactics of resistance, disseminating a spirit of revolt among colonised peoples. But the special space-time of performance seems to exceed this function as well, as if it 
enacts an immanent redistribution of the parts and positions of the colonised world.

The most famous, if brief, account of the relationship between rites of spirit possession and anticolonial resistance is to be found in Frantz Fanon's The Wretched of the Earth. Fanon writes of rituals of possession and dance and argues that these express an 'overexcited affectivity', an 'erotic delight in the muscular deflation of the crisis'. In other words, they express but misdirect a revolutionary energy; in fact, 'vampirism, possession by djinns, by zombies, and by Legba, the illustrious god of voodoo' paradoxically ensure the 'stability of the colonised world'. What has to happen is for the 'colonised subject [to] discover reality' and transform it through revolutionary praxis. ${ }^{28}$ The colonised must and will move away from the libidinal expenditure of pent-up energy in collective rituals of possession to the material harnessing of this energy in the light of a materialist grasp of colonial domination of what reality actually is. To put a spin on this, one could say that dance and possession are tactics for living, techniques for psychic survival under insupportable conditions, but as such need to be left behind through the recognition of the actual insurvivability of colonial domination. The problem, here, is that in this Fanonian schema these are basically primordial rituals that are resurrected in the colonial world because of the muscular energies they allow to be expressed and released; while there is the potential for a dialectical historicisation of these practices (as in the famous analysis of Négritude in Black Skin, White Masks), there is no real sense of them relating actively to a praxis of resistance, nor any account of the repurposing of the forms and iconographies of them in response to colonial domination. They are in essence expressions of false consciousness, where the colonised falsely imagine a possession by spirits rather than apprehending their real possession by colonialism.

What the Hauka suggest, by contrast, are the historical specificity of these rituals, and their power as tools for discovering and reshaping reality on a number of levels. What is witnessed is a performative reversal of colonial power, a seizure of the guise and potentially the perspective, in properly shamanistic manner, of colonial authority. This is certainly subversive: it throws the system into a kind of play, where the various parts and positions are suddenly up for grabs. It de-activates coloniality as a hierarchy of beings, and is a direct expression of animism as a counter-distribution of the animate, in which the colonial organisation of the living and the 'more dead than alive' is reworked. ${ }^{29}$ But Taussig's extravagant reading of the destabilising effects of what he calls 'second contact', as the colonial gaze meets itself represented by the other, implies something more disturbing than a 
mere symbolic rearrangement or counter-distribution of power: "us" and "them" lose their polarity and swim in and out of focus'; a 'dissolution' takes place, as 'stable identity formations auto-destruct into silence, gasps of unaccountable pleasure, or cartwheeling confusion'. ${ }^{30}$ In the moment of second contact the entire project of anthropology as a 'border logistics' of self and other is thrown into question; self and other instead seem to interfuse via a mutual dispossession. So while, for the Hauka (and pace Fanon), spirit possession is expressive of an anticolonial spiritual and material resistance, for Taussig it enacts in the mode of 'second contact' the deconstruction of the anthropological project. Crucially for my argument, this project is understood as the foundation of the very edifice of colonial animism, of us and them, of persons and less-than-persons and things. Could one therefore speak of spirit possession as the expression of a dispossessing animism, since it dissolves the parts and positions of the colonial order? These anticolonial rituals of possession, in stark contrast to the work of colonial dispossession, seem to generate in the space-time of performance a shared dispossession, or even a kind of possessionlessness.

Animism, here, interrupts animism; it exposes a certain inoperativity. If animism is born out of the colonial encounter, and seizes its politicised vocation as a resistance to the status of the object, might it also open onto a further situation, in which the power to objectify or subjectify is ceaselessly deferred and undone? When I speak of animism's dispossession, it is something like this that I mean to gesture towards.

\section{Zong!}

M. NourbeSe Philip's Zong! is an innovative and perhaps completely new kind of poem, which announces an absolute break from post-romantic languages of lyrical expressivity. Zong! is an animist poem, I suggest, in the sense that it imagines language as a vehicle for the release or 'deployment' of forces. It appropriates and also unworks the power of possession, and in doing so confronts and deranges the animist and biopolitical hierarchies of the colonial. The poem does not merely rearrange the parts and positions: it instead interrupts the 'distribution of the animate', unmooring words, sounds and sense from the distributive power of system - including the system of language. It is as if the whole system that would arrange and partition animation and personhood is implicated in colonial violence, such that the task becomes to find a way out of any closed or totalising representation. 
Zong! is not concerned with the seizure of colonial lands but with the enslavement of bodies and the system of de-animation that supports it. The workings of this system are crystallised in the notorious case that gives the poem its title: the case of the Zong massacre. The Zong was a slave ship from which, on a voyage from the Cape Coast to Jamaica, one hundred and thirty three enslaved Africans were thrown overboard. The events began on 29 November 1781, when Luke Collingwood, the captain of the Zong, which was approaching the end of its voyage, ordered that fifty four enslaved women and children be thrown overboard; over the next four days, a further seventy nine slaves were thrown to their deaths. Collingwood believed that if the slaves were 'jettisoned', their loss would be the responsibility of the ship's insurers, whereas if they died a 'natural death' - a phrase Philip is sceptical about (what would a natural death be in this context?) - the slavers would bear the cost. The motivation for Collingwood's actions purportedly related to the scarcity of water following navigational errors, but this claim has been disputed. ${ }^{31}$ The insurers refused to pay, leading to a legal case (Gregson vs Gilbert), heard by Lord Mansfield, through which the Gregson slave-syndicate sought to recover its losses. The verdict in this case was set aside, though Lord Mansfield pronounced that he "had no doubt (though it shocks one very much) that the case of the slaves was the same as if horses had been thrown overboard' ${ }^{32}$

It is difficult to think of a more succinct expression of the logic of chattelisation than Zong, and the Zong massacre became a centrepiece of abolitionist arguments for decades. In response to interventions from the abolitionist Granville Sharp in the Gregson vs Gilbert case, the solicitor-general, John Lee, turned towards the public gallery:

What is all this vast declaration of human beings thrown overboard? The question after all is, was it voluntary, or an act of necessity? This is a case of chattels or goods. It is really so: it is the case of throwing over goods; for to this purpose, and the purpose of the insurance, they are goods and property: creatures if you will — have been thrown overboard: whether or not for the preservation of the rest, that is the real question. ${ }^{33}$

These slaves were not human beings but goods, chattel, moveable property. This plainly expresses a logic of dehumanisation. But what is more disturbing is that the human, in this context, is in fact perfectly compatible with the deanimated status of a thing. Slaves are socially dead but this does not imply that slaveowners and slave traders thought that they 
were not human. ${ }^{34}$ And in fact, the solicitor-general's words reinforce this sense: this 'vast declaration' of human beings is not so much contradicted by the facts of 'the purpose' as it is voided of significance: it belongs to a completely different sphere of (abolitionist) signification.

How does a human being become a slave? Through law but also through magic, or through the law as magic. Here, we are reprising the doubleness of dis-possession. In her 'Notanda' to Zong!, Philip suggests that in the law's

ability to decree what is not, as in a human being ceasing to be and becoming an object, a thing or chattel, [it] approaches the realm of magic and religion. The conversion of human into chattel becomes an act of transubstantiation the equal of the metamorphosis of the eucharistic bread and wine into the body and blood of Christ. ${ }^{35}$

Notwithstanding the magical force of this transubstantiation, slaves are not expelled from the domain of the living. Instead, Philip writes, they are 'in life but without life' (196). The enslaved were also not entirely expelled from the domain of personhood (a slave is recognised to be more 'alive' than a stone), but were instead trapped within the category of the legal slave, a radically degraded form of personhood. ${ }^{36}$ To be 'in life but without life' is to inhabit the world of the living but to be dispossessed of the rights that accrue to full legal persons - including the right to life, to live a life. The doubleness of this 'life' implies something more than the simple fact that the slaves were killed with impunity (robbed of the 'right to life') and bespeaks the included exclusion characteristic of the biopolitical dispensation. ${ }^{37}$ For Philip to link this dispensation with magic is for her to invoke the animistic core of colonial biopolitics.

Zong! uses the report of the Gregson vs Gilbert legal decision as its exclusive source text. As Philip explains: 'I would lock myself in this text in the same way men, women, and children were locked in the holds of the slave ship Zong' (191). Out of this narrow legal document, according to whose dominant protocols the slaves are only considered as property, Philip creates a new text by jumbling phrases, cutting sentences into fragments, iterating words and even breaking them apart. She describes this process as an act of retaliatory violence:

I white out and black out words...I mutilate the text...I murder the text, literally cut it 
into pieces, castrating verbs, suffocating adjectives, murdering nouns, throwing articles, prepositions, conjunctions overboard, jettisoning adverbs...[I] create semantic mayhem, until my hands are bloodied, from so much killing and cutting. (193)

As the poem unfolds the formal violence becomes ever more extreme. While the first section is composed of a sequence of twenty-six numbered poems, recognisable as coherent texts, the later sections become ever more chaotic, until the words themselves are ripped apart: 
write

you

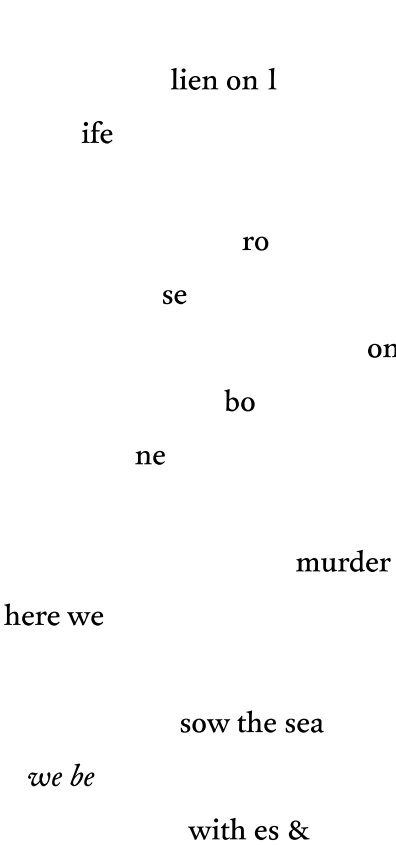

us

got

on

to

of

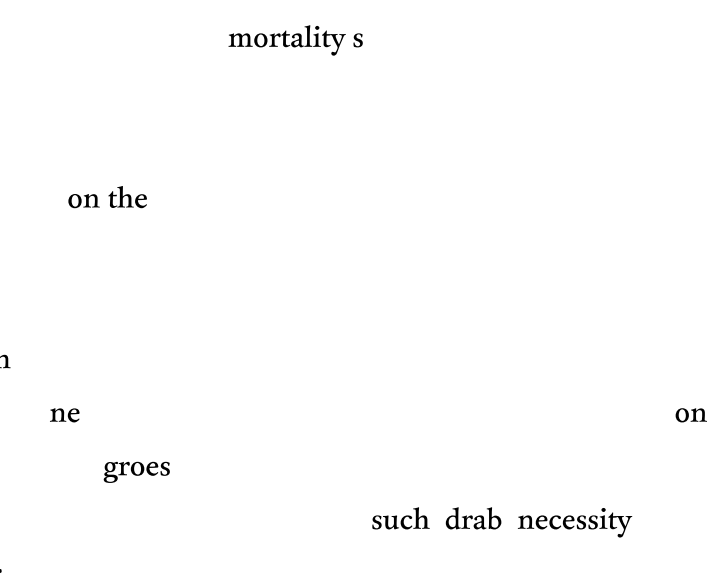

on the

ne
groes

mortality s

like ants

re negroes
like ants
seed the seas $\quad$ is where
oh \& es

$\&$

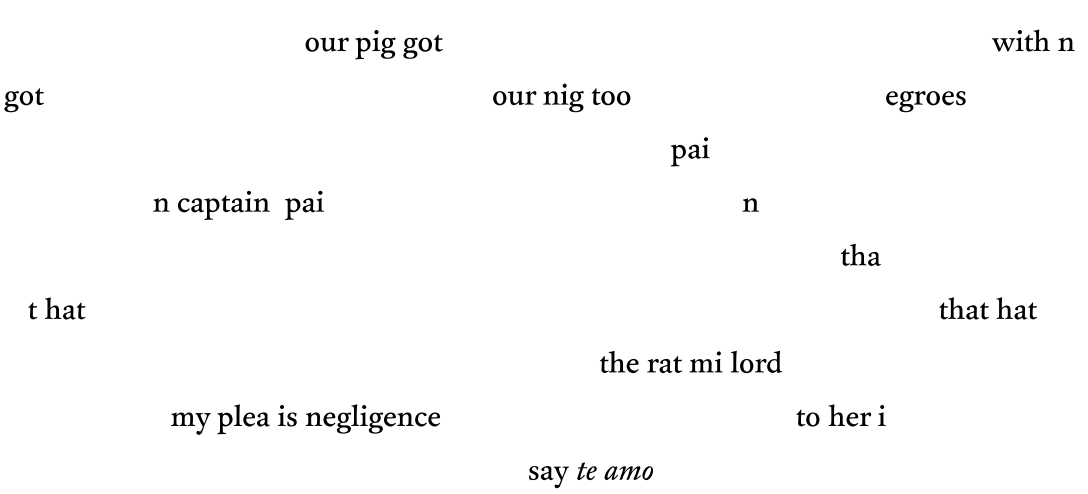

The fragmentation becomes yet more acute, until the poem is scarcely readable: 


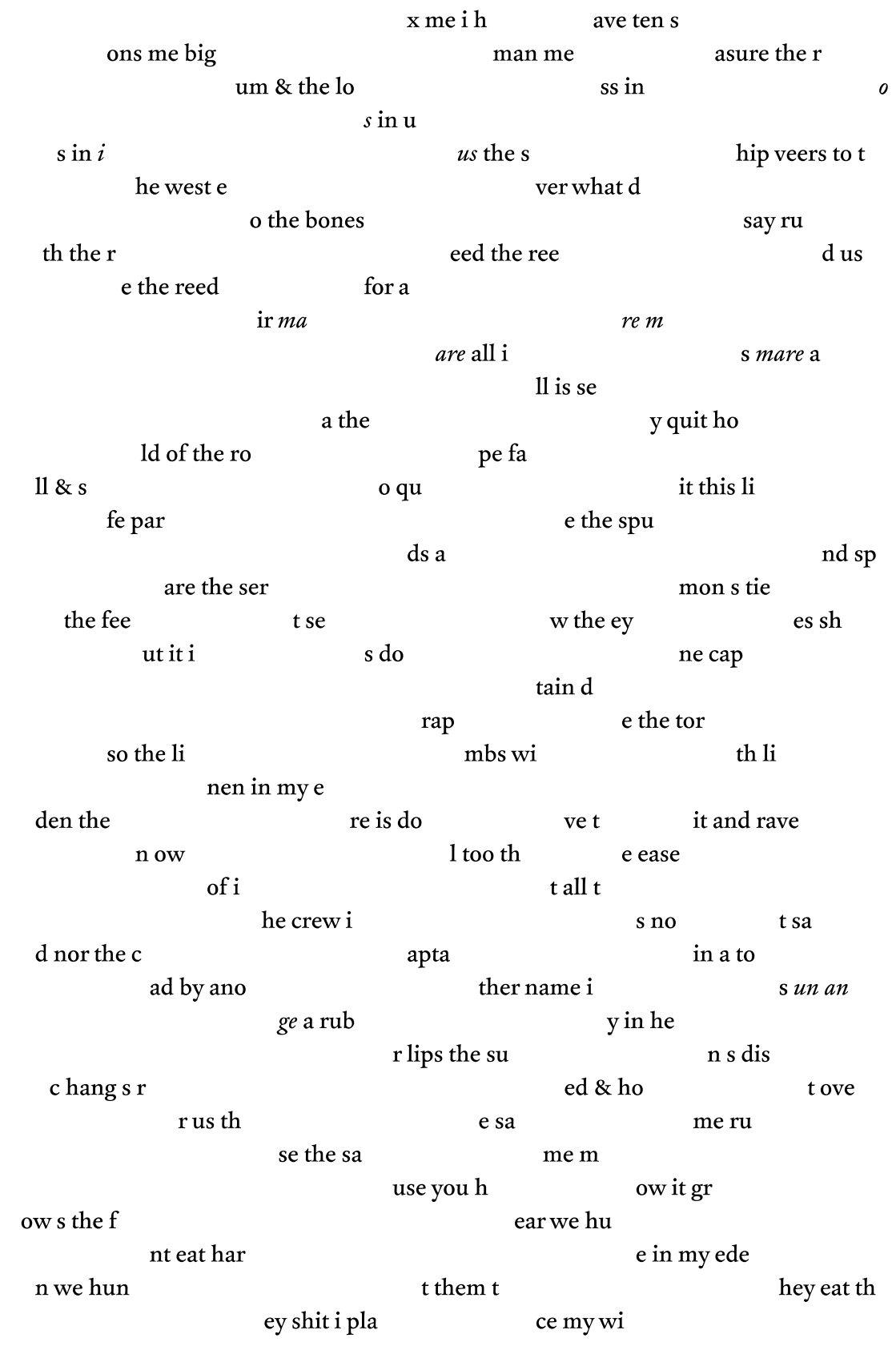

It is as if Philip is tearing apart the cage of the language of enslavement, but to leave us with what (beyond the mayhem, the poet's bloodied hands)?

Zong! is a potent example of a text that exists 'in the wake', to invoke the title of Christina 
Sharpe's book about the ontology of slavery's afterlife. ${ }^{38}$ It refuses almost any gesture of recuperation or rehumanisation of the victims of the event it 'commemorates' (the wrong word in this context), with the possible exception of the inclusion of a number of Yoruba names that run across the bottom of some of the pages. But even these names seem to be debarred from entering the text, from turning the language into the vehicle of a subject or story, of a voice. In a sense the poem extends and even intensifies the depersonalisation of enslavement, as whatever traces exist in the archive dissolve into shape and sound. Why might this be? How might this refusal of repersonalisation reflect the wider politics of this poem's interrupted animism?

In Spectres of the Atlantic, his brilliant study of the relationship between slavery and the history of finance, Ian Baucom uses the case of the Zong massacre to expose the brutal underpinnings of the imaginary of insurance. For Baucom, the murder of the slaves was neither a limit case nor an exception but typical, indeed systematically predictable within the epistemological codes that dominate our financialised age. These codes reduced the slaves' bodies, in advance of their murder, to interest-bearing commodities. But Baucom counterpoints this dehumanising logic with an alternative ethos that would grasp the singularity rather than typicality of the event, and of each death/life it signifies. He explains:

The value of the Zong to an ethics of historical memory depends on its being remembered as an abstractly typical rather than a singular atrocity. [...But] this form of remembrance models its theory of value on the evaluative protocols of that insurance business which underwrote the value of these slaves to their 'owners' and demanded that that value would survive their deaths. ${ }^{39}$

Thus, the number we need to come to terms with is not 133 (the number of slaves thrown overboard) but one: 'One, one, one'. ${ }^{40}$

While Baucom advocates a thought of the singular, however, he risks collapsing the singular into the very different concept of the person: the enslaved were 'entirely singular human beings thrown one by one into the sea' ${ }^{41}$ And yet one might respond by saying that this is precisely what these slaves were not, that in contrast they 'had the shape of human beings but had no human essence whatever'. ${ }^{42}$ Singularity, here, seems indistinguishable from what might more loosely be called individuality or human uniqueness: the individual human 
person, thought once, and then, impossibly, one hundred and thirty three times. Baucom thus advocates a different form of counter-imagining, rooted in 'sympathy and sentiment', than that which we see in Philip's poem. ${ }^{43}$ But the singular, including in the kind of thought from which Baucom draws, such as deconstruction, tends to be a word for what appears in the displacement of historical personhood, of coherent, socialised subjectivity. ${ }^{44}$ The singular implies a different mode of relationality to formal civic or political recognition, with all of its violences and exclusions. These are the exclusions that Sylvia Wynter, in the black radical tradition, describes as man's 'overrepresentation' of himself as the human itself. ${ }^{45} \mathrm{~A}$ particular model of propertied, racialised and gendered personhood becomes the definition of a politically qualified life.

It therefore seems that the project of retrieving personhood from this scenario of radical depersonalisation would not be an untroubled one - even though such a project has a long and important history, most notably in the history of slave narratives. Slave autobiography (a word that began to emerge in the late eighteenth century, when slave narratives grew in number and prominence) was significant for its crucial role in advancing the cause of abolition, and also for its related assertion of the personhood of the enslaved subject (one might say, to echo recent historiographical arguments, that slave autobiography turns the slave into the enslaved subject). Many slave narratives, such as Olaudah Equiano's or Frederick Douglass's, are in essence narratives of conversion. Equiano's, for example, is a narrative of Christian conversion, political conversion (as Equiano becomes an abolitionist) and above all socio-legal conversion: Equiano becomes a free man, having purchased his manumission for forty pounds sterling (a fact repeated a number of times in his narrative). ${ }^{46}$ He publishes his narrative as a propertied man of wealth and status and this undergirds the authority of his account. Brenna Bhandar argues that the modern character of race emerged with ideas of property and associated logics of calculation. She calls these 'economic visions of land and life rooted in logics of abstraction', which are linked to the racial capacity to appropriate. ${ }^{47}$ While Equiano is at pains to emphasise that he has achieved this racialised capacity, most slave narratives offer glimpses of otherwise anonymous lives. The History of Mary Prince, for example — related but not, as in Equiano's case, written by herself — is surrounded by the silence of the archive. All we have is the text itself, dictated to Susannah Strickland, edited and adapted by Thomas Pringle, and published in the same volume as an additional narrative of Louis Asa-Asa. There is no record of whether Prince was ever 
formally manumitted, or of where or when she died. ${ }^{48}$ The exemplarity of an Olaudah Equiano or a Frederick Douglass is counterbalanced by the typicality of a Mary Prince, a Louis Asa-Asa.

The enslaved of Zong were radically anonymous: the archive bears no traces of their names. Or perhaps it would be better to say that they are caught between radical anonymity and the unceasing iteration of the event of their death, even if the complete circumstances of this event will remain obscure. The one hundred and thirty three of Zong (or perhaps one hundred and thirty two - it is possible that one of the jettisoned might have climbed back on board the ship) thus seem a powerful if paradoxical example of what Arthur Bradley calls 'unbearable life', naming lives that have not been lived or that rather have been erased from the record of those who lived or died. Indeed, Patterson's reading of the social death of the slave is a precise expression of this predicament: the slave can never be brought to life again as such since 'the slave will forever remain an unborn being (non-né)'. ${ }^{49}$ Rather than trying to reimagine or repersonalise such life without life, might the task be, as Bradley suggests, to think of it as a new kind of subject position from which to speak or act, or as a new ground(lessness) for biopolitical resistance ${ }^{50}$

Zong! for its part is incapable of reimagining the lives of these slaves outside of the terms bequeathed by the archive. In extending slavery's logic of depersonalisation, Zong!'s response is more akin to that of J. M. W. Turner, in his 1840 painting 'Slavers Throwing Overboard the Dead and the Dying', which was inspired by the same event. There seem to be visual echoes of Turner in some of the pages of Philip's poem, as if the broken words evoke the dispersed fragments of the bodies of the enslaved. ${ }^{51}$ Turner's painting must here be understood less as the disavowal of the enslaved bodies it represents so incompletely than as a devastating expression of the breakdown of systematic constructions of space and time as they attempt to frame the horrors of colonial modernity. As Hito Steyerl puts it:

The observer is upset, displaced, beside himself at the sight of the slaves, who are not only sinking but have also had their bodies reduced to fragments - their limbs devoured by sharks, mere shapes below the water surface. At the sight of the effects of colonialism and slavery, linear perspective - the central viewpoint, the position of mastery, control, and subjecthood—is abandoned and starts tumbling and tilting. ${ }^{52}$ 
This is also to say that in Turner, a new and transgressive animacy — the animacy of the sublime in painting - obliterates the calculative coldness of the imaginary of insurance, even if the painting loses the stability of linear visual perspective in the process. Does anything similar happen in Zong!? If the materiality of paint in Turner emerges out of the ruin of the perspectivised image, could we suggest, in precise analogy, that sound in Philip emerges out of the ruins of linguistic systematicity, of lyrical voice?

\section{Language and Sound}

Philip has recently offered the following visceral description of her experience working as a poet in English:

I have spent my life as a poet and writer exploring what language means for someone like myself, condemned to work in a language that commits a rape in my mouth every time I speak. [...] English is not my mother tongue. It is my father tongue and one which meant me and my mother no good. ${ }^{53}$

Whereas Caribbean poets of an earlier generation such as Derek Walcott rewrote the toxic language of empire as inheritance and as gift, ${ }^{54}$ Philip feels 'plagued' by having to work with a language 'contaminated by its history of empire and colonialism' ${ }^{55}$ This hostility to language finds an intense expression in Zong!. But in Zong! this hostility is specifically linked to language understood as a tool of law-as-magic, as the vehicle of a violent 'transubstantiation'. This transubstantiative agency, at once magical and material, operates of course through a relentlessly rationalistic idiom, calculative and legalistic. The poem mimics this idiom, but in doing so imbues it with the strange incantatory power that it would disavow: 
Zong! \#24

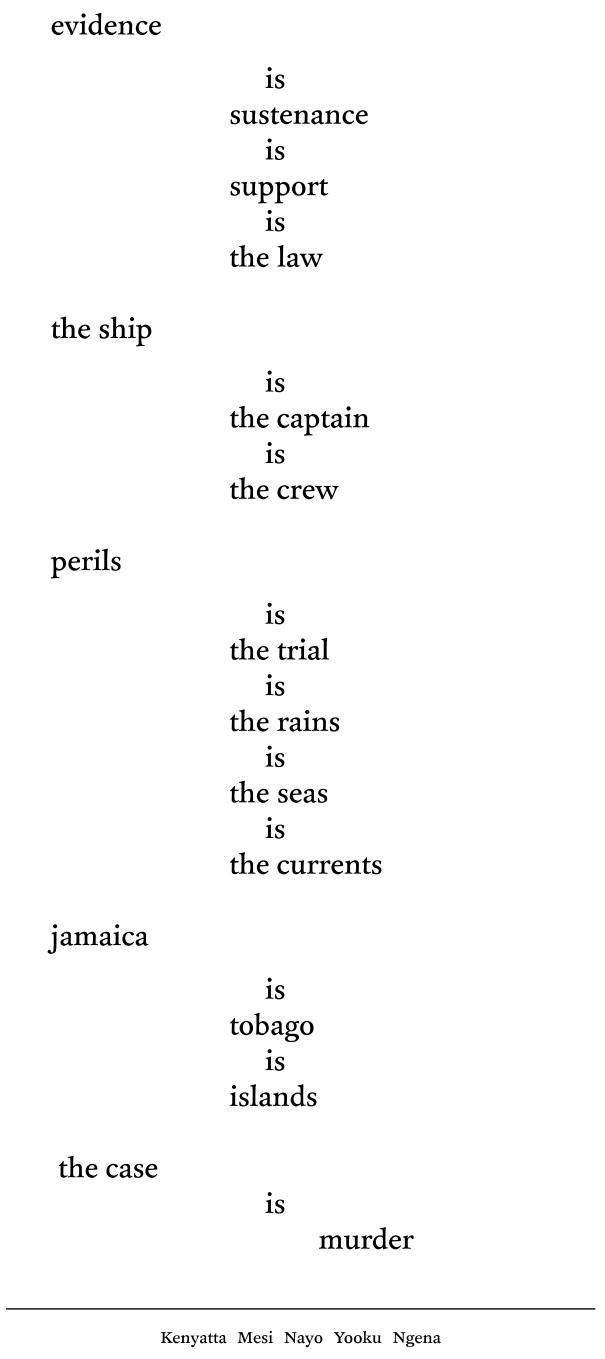

This rigid language of analytical sense seems to have become a magical recitation, a kind of spell. Is this language not animistic, not dedicated to the deployment of forces? These lines mimic the copulative force of the law, its immediative and transubstantiative power (as in the Eucharistic 'This is my body'), but what they also do is introduce a strangeness and 


is
justice
africa
is
the ground
is
negroes

evidence is

sustenance is

support is

the law is

the ship is

the captain is

the crew is

perils is

the trial is

the rains is

the seas is

currents is

jamaica is

tobago is

islands is

the case is

murder is

justice is

the ground is

africa is

negroes

was

Oluyemi Esugbayi Adubifa Ogunlesi Akua

42

It is as if, at the risk of overdetermining the text, this spell leads to the production of 'negroes 
... was', in the past tense, but it is equally that this shift in tense introduces historical memory into this immediative spell, such that it pauses in irresolution, hesitates - in contrast to the mock finality of the final line on p. 41 .

This section is typical of the larger text, in the sense that it captures a dilemma between nonsense, or what Philip calls 'pure utterance', and some alternative regime of critical sense, if an elusive one: Philip describes fighting the desire to impose meaning on these words (194). There is a certain difficulty or effortfulness, captured by the interruption of rhythm and the spacing of the words (these poems are visual as much as textual artefacts) to the effort to shift the object of consideration, to recover those who have been imaginatively jettisoned. A similar effect occurs in Zong! \#14: 
Zong! \#I4

the truth was
the ship sailed
the rains came
the loss arose

the truth is

the ship sailed

the rains came

the loss arose

the negroes is

the truth was

Nkrumah Ato Nobanzi Oduneye Opa Fagbulu

24

The penultimate line seems to interrupt this litany of 'truth', to disturb the banal simplicity of the account, of accounting. What emerges here is at once a biting satire, a derangement or bemaddening of the constricted sense of the law of slavery and insurance, and an effort to resist the spell and the sentence of history. 
Zong!'s hostility is also directed towards the language and form of lyric poetry. Post-romantic lyricism defines most of our senses of what poetry simply is: a language to capture the thoughts, feelings or impressions of a speaker in place and time, with the 'tacit assumption' that it is a 'univocal and authentic form of self-expression'. ${ }^{56}$ Sarah Dowling argues that Zong!, by employing lyric modes such as apostrophe, seeks to 'reanimate the lost slaves' and to 'endow them with some degree of lyric if not legal personhood by giving them names'. ${ }^{57}$ Dowling builds her interpretation out of Barbara Johnson's reading of how lyric encodes a relationship between the first-person ' $I$ ' of the poem and the legal or constitutional person of the law. ${ }^{58}$ Lyric and the law are both rooted in a familiar idea of coherent and agential personhood; the implication is that Zong! works against the law's work of de-personalisation in this context. My argument is more sympathetic with Alexandra Schultheis Moore's: for Moore, Philip's conjurings are less about borrowings from lyric poetry (which indeed seem scant) than about 'manifest[ing] the radical dispossession of the subject' in a condition of 'non-being'. 59

Lyricism is about the univocal, the single voice, which generates the effect or illusion of the coherent person. Zong! is more productively considered as a ruined lyric, which does as much premeditated violence to the language of poetry as to the language of the law. What happens to language in the performance of the poem? What appears in the wake of poetry's murder? This is where the phenomenon of sound begins to emerge. Sound, in Philip, may be considered the alternative to voice, even as its negation.

In his book In the Break, Fred Moten articulates a relationship between objecthood and sound. He departs from various sources: Édouard Glissant, in his declaration in Caribbean Discourse that 'din is discourse', that the word for the slave is 'camouflaged' under the 'provocative intensity of the scream'; Frederick Douglass, with his description of the 'wild notes' and 'ineffable sadness' of the slave songs that are a truer witness to the horror of enslavement than Aunt Hester's shrieks; Karl Marx, whose speculation about the commodity who speaks is crossed over by the human commodity who really speaks or screams. Moten distinguishes his argument from the ideas of Ferdinand de Saussure, who claimed that sound is 'merely something ancillary, a material the language uses': 'Linguistic signals are not in essence phonetic. They are not physical in any way. They are constituted solely by differences which distinguish one such sound pattern from another'. ${ }^{60}$ Language for Saussure 
is dead sound, but for Moten it is in the phonetic, in the 'phonic materiality' of sound, that something like subjectivity - even if completely disaggregated from personhood — may make itself felt. This 'phonic materiality' is connected to a 'dispossessive force', which testifies to the fact that in the 'history of blackness .... objects can and do resist' ${ }^{61}$

Moten's reading of the 'dispossessive force' of the phonic comes very close to an animist conception of language. In the structuralist view, at least as Moten presents it, language is an essentially non-phonetic system which happens to use sound as a mere material. But in animism, language is about immediation, and sound thus acquires a potentially irreducible, indeed a magical power. Here we are some distance from a representationalist account of language or of literature, which implies a distanced and unidirectional referentiality - a kind of 'possession' of the object, in which the represented is debarred from entering into or interanimating the language that summons it. Sound in contrast is the locus of some occult sympathy, which 'expresses', if one may use a word with such lyrical underpinnings, a subjectivity or witness outside of the bounds of personhood. One may think of sound, more precisely, as the expression of a singularity that withdraws from or dispossesses the construct of Man. ${ }^{62}$

Philip's poetry reaches for the sound within or in the wake of language. If language captures sound within a system of signification, it is sound that persists as the residue of language in the event of its breakdown, its corruption. Consider the opening to the very first poem of Zong!: 


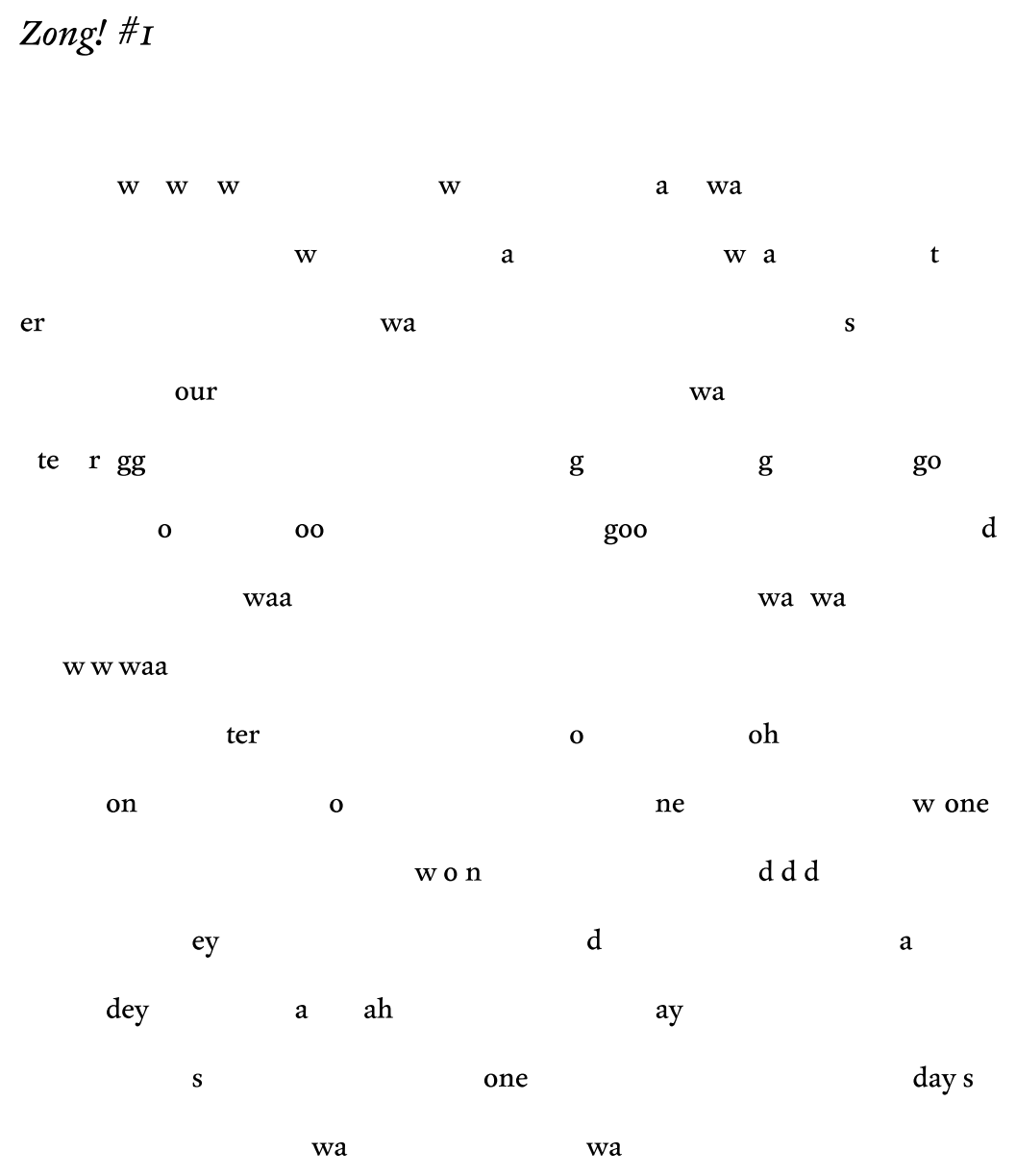

Masuz Zuwena Ogunsheye Ziyad Ogwambi Keturah

Visually, words devolve into their component letters; it is as if they are submerged, and as if sense is drowning with them. In composing the poem, Philip imagined that her project was akin to exhuming bodies, only to discover that there is no word to describe 'exhuming' those who are drowned at sea (201). There are after all no graves; there is no location to mark 
subaquatic death. Is it for us to 'exhume' sense from these dispersed fragments? The key word here is water; followed by good; and then (further down the page) 'o', 'oh' (an exclamation?). By reading it aloud we can reach an approximation of 'one day's water' resonating with the historical suggestion that water on the ship was low (is this a shipboard conversation we are overhearing?). On the following page we have 'ant', and a phrase that occurs later is the 'want of water'. Thus some sense of pattern begins to emerge: this is a negation of one regime of sense, but it is not nonsense.

Yet it is also not voice. The poem remains irreducibly ambiguous, and as it unfolds its resistance to interpretation becomes more stubborn, the 'logic' of its rhythms and patternings more difficult to parse. The poem inhabits the threshold between sense and nonsense, and this threshold maps onto its larger project: the challenge Zong! undertakes is to release the ghosts of the archive from silence and representation, from de-animation and re-personalisation. What we witness or hear is the possessive power of language in ruins.

In the 'Notanda' Philip speculates about water as a sound-efficient medium; she wonders whether the sound of the slaves, their 'wails, cries, moans, and shouts', resounded under the sea (203). These sounds resurface in Zong!, in its language of 'grunt and groan, of moan and stutter' (206). This resounding might be lyrical but only in the most primordial sense, implying a lyric not of language but of an ecstatic song, heard 'at the beginning of time': 'Zong! is chant! Shout! And ululation! Zong is moan! Mutter! Howl! And shriek! [...] Zong! is Song!' In this light, it is clear that Philip's project firmly rejects not just the discourse of legal slavery but also the protocols of historical fiction, which generally aim to recover the voices of history and reincorporate them into the present imaginary. ${ }^{63}$ Philip's phonic counter-animism is more about a kind of disincorporation: the process by which the thing is broken free of its corporate body (the archive, the slave ship, language, fiction) and disclosed, dispersed, discovered.

\section{Spiritual Baptism}

In her impressionistic essay 'Wor(1)ds Interrupted' Philip asks whether Zong! is 'a ritual work masquerading as a conceptual work', where ritual is 'perhaps the way through the unsayable'. ${ }^{64}$ In the same essay and elsewhere, Philip has parsed this 'ritual' element in 
relation to Spiritual Baptism. Indeed, Philip has stated (or joked) that she 'outs herself' as a 'closet Spiritual Baptist' each time she performs the poem. ${ }^{65}$ This dimension of the poem has been almost entirely overlooked in the rapidly growing body of criticism on Zong!. A small handful of critics have recognised that Zong! is a performance poem as much as a text for private reading, and noted some of the ways in which this performance is ritualised, but none have observed how this ritualisation borrows elements from Spiritual Baptism. ${ }^{66}$

Spiritual Baptism is a syncretic religious practice: it subscribes to a Christian theology but incorporates Africanist practices of spirit possession. ${ }^{67}$ It is an originally Caribbean religion, most associated with Trinidad and St. Vincent, but is also practiced in Caribbean diasporic communities around the world. Its status as 'religion' though has historically been vexed. Spiritual Baptism ('Shakerism' or 'Shouter Baptism' as it was formerly known) was outlawed in St Vincent in 1912 and Trinidad and Tobago in 1917, the culmination of decades of persecution against practitioners (in St Vincent, Spiritual Baptists call themselves the 'Converted'). ${ }^{68}$ A report on Vincentian 'Shakers' in Trinidad from the 1890s captures the colonial attitude:

An abominable nuisance has been created in town by the arrival from St Vincent, it is believed, of a pack of fools described as "Shakers". They hold what they call religious meetings and perform all manner of weird incantations accompanied by hideous yelling and riotousness which cannot but convince one that they are a band of lunatics calling for immediate confinement. They jump and skip and walk on their hands and go through a series of wild antics in the back streets - like so many brutes "possessed by the devil" - to propitiate "the spirit". ${ }^{69}$

The ordinances which followed, interestingly, were connected to the prohibition of Obeah: both were seen to challenge the legitimate mechanisms of colonial authority, such as institutionalised Christianity, and both were connected to subversive forms of apparently 'African' bodily and ritual practice. ${ }^{70}$ These ordinances were adapted from older antivagrancy laws, as if they targeted these practices of the dispossessed because of the proof they gave of an alternative distribution of possession, power and animation.

While Spiritual Baptism is uncontroversially linked to African rituals of spirit possession, it is important to recognise the colonial nature of the religion: it is not merely syncretic in the 
sense that a residual animism is interfused with a new world Christian theology, but in the historical and political sense that it is born out of the colonial situation. Thus the historical experiences of enslavement, the Middle Passage, and other colonial migrations are intermingled with scripture. The title of Wallace Zane's book on Spiritual Baptism, Journeys to the Spiritual Lands, refers to the central experience of 'journeying' within the religion, where the pilgrim (a kind of shaman) travels in and via the Holy Spirit not only to Biblical lands but also to the sources of colonial labour: Africa, India, China — and even (quite often) the bottom of the sea. ${ }^{71}$

This ritual of spiritual subversion is called 'mourning'. There are many important rituals, but Zane describes mourning as the definitive one. 'Pilgrims' are enclosed within a mourning room in which they undertake their journey, which might last for a day or weeks, and which involves fasting, prayer, and spirit possession. The 'shouting' is the name for the report of this experience of spiritual journeying: it might begin, 'I found myself in Africa', as the pilgrim gradually translates their ecstatic experience into the language of the temporal world. Zane distinguishes between 'churchly' and 'shamanic' aspects of the religion, where churchly rituals enable the interpretation of the temporal world and where the 'shamanic' enact a 'ritual subversion' of it. ${ }^{72}$ The shout rearticulates the ecstatic experience in social and communal terms: while the shout may begin within the state of possession, manifested in excessive bodily effects (such as shaking), the aim of this ritual is to achieve control over this condition, in order to transfer it into the work of what is called (in St. Vincent) 'doption'. The idea is to give some order to spirit possession, in order to put it to work. ${ }^{73}$

The shout therefore mediates between the churchly and the shamanic, the worldly and the otherworldly orientations of Spiritual Baptism. But the distinction between these realms and vocations seems to be productively unstable. If shouting translates ecstatic experience into a legible communal language, it is equally true that this work of translation is restlessly undone. Mourning is an ongoing and unending labour for the Converted, because what is being mourned is the condition of temporal life itself ('your sins'). ${ }^{74}$ Shouting in this sense is as much a call to mourning as the dissemination of an experience.

The priority of forms of ritual subversion, or even ritual 'amelioration', must be connected to the experience of colonial dispossession and ongoing poverty and marginalisation. Zane explains: 
The order of the secular world, with policeman and soldiers and teachers and captains and doctors and nurses - all people who must be obeyed — is inverted. The Spiritual Baptists become by name and title police inspectors, corporally punishing teachers, captains of ships - all positions unavailable to them in the "natural" world. The horrors of slavery, the horror of the memory of slavery, the difficulties of colonial oppression, are effaced symbolically in Converted religion by the seizure of control of those very same oppressive structures. ${ }^{75}$

The Converted are far from unique in this light: Zane mentions the famous 'Cargo Cults' of Melanesia, and Taussig and Stoller's work on the Hauka resonates here as well. Zane later references Jean Comaroff's work on the Tshidi Zionists in South Africa, whose 'structural predicament condemns them to reproduce the material and symbolic forms of the neocolonial system' but who nevertheless 'address and redress experiential conflict'. Spiritual Baptism, similarly, gives 'access to a spiritual world where the dominant position[s] ... are now occupied by the Converted themselves'. ${ }^{76}$ But this raises the broader question of my argument: do the states of ecstasy or ritual dispossession that are produced by the shamanistic elements of Spiritual Baptism (the classic work on shamanism by Mircea Eliade is subtitled Archaic Techniques of Ecstasy) really subvert the worldly order, or do they produce a reorganised economy of symbolic power in which the fundamental structure of the social order is unaltered, even within the realm of spirit? This question perhaps reflects an inherent ambivalence, but it directly pertains to the performative work of Zong!.

Zong! has been performed at arts festivals and academic conferences, in museums, public parks, and community centres. I witnessed a performance in summer 2014 in Trinity Bellwoods park in Toronto. Philip read from the poem, but this reading felt like an authentic transfiguration, or activation, of the text. The phonic materiality of the poem's language emerged unmistakably. Daniel Benjamin offers an excellent description of Philip's enunciation of the word 'water' in a performance in the US, of how 'her lips slowly tremble the letter "w", such that we hear 'the vibrating vocal cords along with the trembling lips'.77 This is the phonic as disturbance, even as the disturbance of 'New World configurations of value', to quote from Lindon Barrett's work, which Philip herself quotes at the opening of her book of essays, BlanKK. ${ }^{78}$ The performance was also distinctly ritualised. There were torches to mark the performance area (creating a sacred or 'set apart' space); Philip, and other 
helpers, wore the distinctive white robes associated with Spiritual Baptists; the performance involved expressive movement; it was also participatory, as extracts of the poem were shared and we were invited to speak, recite, or move as well. Thus there was a strongly improvisatory element, which included Philip's extemporised adaptations of the text.

This performance might be interpreted as a kind of shout, or as a combination of the rituals of mourning and shouting, as if the experience of journeying itself, traditionally a private (though facilitated) experience, has become a shared one. The words and sounds of this performance are as much a vehicle of the journey as they are a communication of it: they enact and immediate, animistically, the work and experience of mourning. If there is a distinction to be made between the churchly and shamanic in Spiritual Baptism, the two elements in Zong! have been decisively fused. This performance is less about making sense of the text (as in the churchly) than it is about making power out of it. But this is a paradoxical kind of power. This ritual performance opens not onto a rearrangement of the hierarchy of persons and souls, but onto a power of potential dispossession that extends at least across the space and duration of performance.

In Spiritual Baptism, shaking, screaming, and shouting are supposed to be controlled, as the shamanic is subordinated to the churchly, so that these energies can be directed into the production of a particular kind of knowledge, a particular kind of resistant social formation. With Zong! this movement from the shamanic to the churchly is uncertain. Thus Zong!, interpreted through its performance, appears as a specific adaptation of Spiritual Baptist ritual. This ritual is inherently related to the experience of colonial dispossession and enslavement: where else does Zong! take us other than to the bottom of the sea? What is being conjured is the very subversive and decolonial spirit of spirit possession. Like Spiritual Baptist mourning, and other anticolonial rituals, the poem enacts a resistance to the condition of degraded life. But this resistance to degradation itself initiates a certain degradation, because it breaks down the hierarchical order of animation and personhood that undergirds the construct of Man - even to the extent of magically dissolving the border between the living and the dead. If the poem's deracinated words and sounds are a witness to what Orlando Patterson calls the 'natal alienation' of the enslaved, they are also a subversive gesture insofar as they unwork this colonial systematisation of life.

The poem offers no compensation for the history of enslavement and coloniality; it reserves 
no capacity to retrieve and restore degraded life. Instead, the poem's degraded form, encountered most powerfully in the sound of its performance, enacts a certain sympathy with, a mimetic relation to, this condition of degradation. Zong!'s is not a human or socially legible language; it is the language of the body excluded from the biopolitical order, of the body that is, animistically, unreadable. Philip herself uses an instructive term, derived from the sales book of a slave agent: the meagre. ${ }^{79}$ Zong!'s ecstatic and also formless or deformed language expresses and even affirms the condition of meagreness.

Zong! therefore cannot reverse the transubstantiation by which the human became chattel; it cannot reanimate the ghosts or exhume the bodies. But it does enact a different and nondominative form of magic. The poem indeterminates the relationship between possession and dispossession, animation and de-animation. It exposes the dark magic of chattelisation and in turn 'auto-destructs', or at least exits, the biopolitical machine of animism. As Philip utters her sounds - from the bottom of the sea, from the beginning of time — she is inviting us to commune with a life that circulates outside of the hierarchies of colonial animism, to enter into the vicinity of a depersonalised form of animation. In this sense, I have been arguing, the poem constitutes a ritual disclosure of the process by which animism escapes animism as a distributive system, in order to conjure something outside of the colonial order of being: an animacy rather than a life, a sound rather than a voice, presences rather than a person.

If animism, as Harry Garuba asserts, is the 'included exclusion' of colonial modernity, then it is problematic to assume that it can provide the tools to transcend coloniality's violence. ${ }^{80}$ My aim has been to locate animism within the scene of colonial violence, and to keep it there. Rather than extracting animism as an emancipatory alter-cosmology, I have aimed to follow the process by which it might unfold a logic of autodestruction or autodegradation that undermines its own distributive project. If it is possible to degrade the opposition between biopolitical rationality and animistic possession by observing their shared investments in the distribution of animacy, as in a hierarchical structure of personhood that maps different intensities of aliveness, then this animistic autodegradation - what I have parsed as its dispossession of itself - is also, as we see in Zong!, the process by which the assumptions of biopolitical animism can be radically disturbed. For animism to resist biopolitics, in other words, it has to become something other than animism: it has to sabotage the machine that would administer the distribution of the animate, in all of the ways I have described. 
If it is clear that Philip's poem undertakes disruptive work, refusing the reclamation of voice or the rearticulation of personhood, it also needs to be recognised that something becomes possible in the disruption of these projects of representation and reclamation: the system by which people possess themselves and are possessed needs to be rendered dispossessive before these more obviously affirmative projects can begin to make sense. While Zong! lives 'in the wake', what resonates within it is also a longer history of rituals of anticolonial subversion, with their insurrectionary powers. This context is important. In extemporised adaptations of the text in performance, Philip will sometimes include names of contemporary victims of police brutality in the US and Canada, bringing the poem's long view of racist brutality into focus and intersecting with the emergent politics of Black Lives Matter. In a way that seems akin to Claudia Rankine's list of names in Citizen, which are invoked and disappeared by the poem as the print on the page fades out, these names are summoned but not restored. ${ }^{81}$ But these references underscore how the poem positions itself in and as a site of struggle: to put it in the terms from Zane above, its work is shamanic and churchly. But with the endless adaptability of systems of racist domination and the ever intensifying investments in partitioning and hierarchising the domain of the living, it is clear that this combat cannot be won on this stage alone, as the poem mourns at once for the necessity and insufficiency of its own churchly-shamanic, worldly and animistic power.

1 Achille Mbembe defines necropower as the power to dictate 'who may live and who must die' (11). Mbembe is extending Foucault's complication of his famous formulation of biopower as the power to 'make live and let die', according to which death (unlike mortality) is something that power 'literally ignores' (248). Foucault explains how racism provides the precondition for the modern state to institute a break between 'what must live and what must die' (254-6). The intimacy of biopolitics and necropolitics is therefore definitively colonial. In Achille Mbembe, 'Necropolitics', Public Culture 15.1 (2003): 11-40; Michel Foucault, Society Must be Defended: Lectures At the Collège De France: 1975-1976, trans. David Macey (New York: Picador, 2003).

2 Nurit Bird-David, “"Animism” Revisited: Personhood, Environment, and Relational Epistemology', Current Anthropology 40.S1 (1999): 67-91.

3 Graham Harvey, Animism: Respecting the Living World (New York: Columbia University Press, 2005).

4 Tim Ingold, 'Rethinking the Animate, Re-Animating Thought', Ethnos 71.1 (2016), 10.

5 Eduardo Viveiros de Castro, Cannibal Metaphysics, trans. Peter Skafish (Minneapolis: University of Minnesota Press, 2017), 42, 78.

6 See, for example, Joseph Josephson-Storm, The Myth of Disenchantment: Magic, Modernity, and the Birth of the Human Sciences (Chicago: University of Chicago Press, 2017). Relevant contexts here include the animism of Marxian commodity fetishism and Freudian psychoanalysis, and the occultist roots of the Frankfurt school.

7 Mary Louise Pratt calls this the discourse of 'anti-conquest', in which an apparently benign observational imperative serves to encode the sovereignty of the imperial imagination. In Imperial Eyes: Travel Writing and Transculturation (London and New York: Routledge, 1992). 
8 Harvey, Animism, 6.

9 Theodor Adorno and Max Horkheimer, Dialectic of Enlightenment, trans. John Cumming (London: Verso, 1997), 5.

10 Jacques Rancière, The Politics of Aesthetics, trans. Gabriel Rockhill (London: Continuum, 2006), 85.

11 See Harvey, Animism, 5-16, for a lucid explication of the key thinkers of the 'old' animism, such as Tylor, Durkheim and Stewart Guthrie.

12 Bruno Latour, 'Agency At the Time of the Anthropocene', New Literary History 45.1 (2014), 7.

13 Harvey, Animism, 18. See Irving Hallowell, 'Ojibwa Ontology, Behaviour, and World View', (eds), Culture in History: Essays in Honor of Paul Radin ed. Stanley Diamond (New York: Columbia University Press, 1960).

14 Viveiros de Castro, Cannibal Metaphysics, 57. On perspectivism as animism, see 54-55.

15 Jane Bennett, Vibrant Matter: A Political Ecology of Things (Durham, NC: Duke University Press, 2009), 6.

16 On the politics of new materialism, see for example Dipesh Chakrabarty, 'The Planet: An Emergent Humanist Category', Critical Inquiry 46.1 (2019), 30.

17 Laurent Dubreuil, Empire of Language: Toward a Critique of (Post)colonial Expression (Ithaca: Cornell University Press, 2013), 17.

18 Christopher Bracken, Magical Criticism: The Recourse of Savage Philosophy (Chicago: University of Chicago Press, 2007), 146.

19 Bracken, Magical Criticism, 4.

20 Giorgio Agamben, The Open: Man and Animal, trans. Kevin Attell (Stanford: Stanford UP, 2004), 15.

21 Bracken, Magical Criticism, 2.

22 The figure of the shaman is important to this, as someone who actively administers the relations among different 'parts and positions' on the animist spectrum. See Viveiros de Castro, Cannibal Metaphysics, 60.

${ }^{23}$ See Lorraine Daston and Peter Galison, Objectivity (New York: Zone, 2010), for a discussion of the emergence of objectivity in nineteenth-century science as a kind of 'blind sight', a kind of knowledge, even, that would 'bear no trace of the knower', lacking 'inference, interpretation, or intelligence' (1517). The point is that this 'blind sight' shunned perfection or idealisation in favour of a mechanical record of natural form as it actually appears, but this non-idealised sight is its own kind of idealisation.

24 See Johannes Fabian, Time and the Other: How Anthropology Makes Its Object (New York: Columbia University Press, 1983).

25 Michael Taussig, Mimesis and Alterity: A Particular History of the Senses (New York and London: Routledge, 1993), 241.

26 Paul Stoller, Fusion of the Worlds: An Ethnography of Possession Among the Songhay of Niger (Chicago: University of Chicago Press, 1997), 152. See also Paul Stoller, 'Horrific Comedy: Cultural Resistance and the Hauka Movement in Niger', Ethos 12.2 (1984), 176.

27 Taussig, Mimesis and Alterity, 240.

${ }^{28}$ Frantz Fanon, The Wretched of the Earth, trans. Richard Philcox (New York: Grove Press, 2004), $18-21$.

29 Fanon, The Wretched of the Earth, 14.

30 Taussig, Mimesis and Alterity, 246.

31 Andrew Lewis, 'Martin Dockray and the Zong: A Tribute in the Form of a Chronology', Journal of Legal History 28.3 (2007), 366.

32 James Walvin, Black Ivory: A History of British Slavery (Washington DC: Howard University Press, 1994), 17.

33 Walvin, Black Ivory, 19.

34 See Orlando Patterson, Slavery and Social Death: A Comparative Study (Cambridge: Harvard University Press, 1982), or Grégoire Chamayou, Manhunts: A Philosophical History, trans. Steven Rendall (New Jersey: Princeton University Press, 2012).

35 Marlene NourbeSe Philip, Zong!: As Told to the Author By Sataey Adamu Boateng (Toronto: 
Mercury Press, 2008), 196.

36 Patterson, Slavery and Social Death, 22. See also Alexandra Schultheis Moore, "'Dispossession Within the Law": Human Rights and the Ec-Static Subject in M. Nourbese Philip's Zong!', Feminist Formations 28.1 (2016), 179.

37 Giorgio Agamben, Homo Sacer: Sovereign Power and Bare Life, trans. Daniel Heller-Roazen (Stanford: Stanford University Press, 1998), 18. See also Patterson again, on how the man 'who was enslaved was in a permanent condition of liminality and must mourn forever his own social death' (60).

38 Christina Sharpe, In the Wake: On Blackness and Being (Durham, NC: Duke University Press, 2016).

39 Ian Baucom, Specters of the Atlantic: Finance Capital, Slavery, and the Philosophy of History (Durham: Duke UP, 2005), 47.

40 Baucom, Specters of the Atlantic, 131.

41 Viveiros de Castro, Cannibal Metaphysics, 131.

${ }^{42}$ Patterson, Slavery and Social Death, 47. An ontologised version of this claim can be found in Frank Wilderson's Afropessimism (New York: Liveright, 2020), in which he makes the claim that 'the antagonist of the worker is the capitalist. The antagonist of the Native is the settler. But the antagonist of the Black is the Human being' (241). For a comprehensive critique, see Jesse McCarthy, 'On Afropessimism', Los Angeles Review of Books, 20 July 2020, n.p..

43 Baucom, Specters of the Atlantic, 193. For a more developed critique of the liberal rhetoric of sympathy and the implicit limitations it imposes on the powers of literature, see Philip Dickinson, 'Feeling, Affect, Exposure: Ethical (In)capacity, the Sympathetic Imagination, and J. M. Coetzee's Disgrace', Mosaic 46.4 (2013): 1-19.

44 In Jean-Luc Nancy, for example, the concept of the singular sits at the centre of a web of interconnected terms, such as exposure, spacing, touch and community. The singular emerges in privileged relation to touch, for instance, because touch opens up a different relationality, a different or 'inoperative' community.

45 Sylvia Wynter, 'Unsettling the Coloniality of Being/power/truth/freedom: Towards the Human, After Man, Its Overrepresentation — an Argument', CR: The New Centennial Review 3.3 (2003), 260.

46 Olaudah Equiano, The Interesting Narrative and Other Writings (London: Penguin, 2003).

47 Brenna Bhandar, Colonial Lives of Property: Law, Land, and Racial Regimes of Ownership (Durham, NC: Duke University Press, 2018), 6.

48 Sara Salih, ed. The History of Mary Prince (London: Penguin, 2000).

${ }^{49}$ Michel Izard, quoted in Patterson, Slavery and Social Death, 38.

50 Arthur Bradley, Unbearable Life: A Genealogy of Political Erasure (New York: Columbia University Press, 2019), 19-20.

51 See for example Philip, Zong!, 3-4, 63, 79-98.

52 Hito Steyerl, The Wretched of the Screen (Berlin: Sternberg Press, 2012), 23.

53 Marlene NourbeSe Philip, Blank: Essays and Interviews (Toronto: Book*hug, 2017), 31.

54 Derek Walcott, What the Twilight Says: Essays (New York: Farrar, Straus and Giroux, 1998).

55 Philip, Blank: Essays and Interviews, 31.

56 Marjorie Perloff, 'Postmodernism / Fin De Siècle: Defining 'Difference' in Late TwentiethCentury Poetics', in Edward Larrissy (ed.), Romanticism and Postmodernism (Cambridge: Cambridge University Press, 1999), 200.

57 Sarah Dowling, 'Persons and Voices: Sounding Impossible Bodies in M. Nourbese Philip's Zong!', Canadian Literature 210/211 (2011).

58 Barbara Johnson, 'Anthropomorphism in Lyric and Law', Yale Journal of Law and Humanities 10.2 (1998).

59 Schultheis Moore, “Dispossession Within the Law": Human Rights and the Ec-Static Subject in M. Nourbese Philip's Zong!', 181.

60 Fred Moten, In the Break: The Aesthetics of the Black Radical Tradition (Minneapolis: University of Minnesota Press, 2003), 13.

61 Moten, In the Break, 1. 
${ }^{62}$ See James Burton's discussion of 'Manimism' in his contribution to this special issue.

63 One might compare Fred D'Aguiar's Feeding the Ghosts, which narrativises an imagined rebellion on board the Zong and privileges the first-person testimony of Mintah, a slave who is thrown overboard but manages to climb back on board the ship. Philip seems to reference this novel in the 'Notanda', but for her a novel 'requires too much telling' (190).

64 M. NourbeSe Philip, 'Wor(1)ds Interrupted: The Unhistory of the Kari Basin', Jacket2 (2013): n. p. [web], accessed 12 Mar 2020.

65 Duke Franklin Humanities Research Institute, 'M. Nourbese Philip: Zong! And the Black Outdoors', 8 Aug 2017, YouTube video, 28:55, accessed 12 Mar 2020.

66 Lambert, Siklosi and Benjamin all discuss specific performances of the poem. Khan connects the sonic elements of Zong! with lamentation. In Laurie Lambert, 'Poetics of Reparation in M. Nourbese Philip's Zong!', The Global South 10.1 (2016): 107-129; Kate Siklosi, “"The Absolute / of Water": The Submarine Poetic of M. Nourbese Philip's Zong!', Canadian Literature 228/229 (2016): 111-130; Daniel Benjamin, 'On Ecstatic-Aesthetic Universality—in Zong!', Small Axe 23.1 (2019): 17-34; Almas Khan, 'Poetic Justice: Slavery, Law, and the (Anti-)elegiac Form in M. Nourbese Philip's Zong!', Cambridge Journal of Postcolonial Literary Inquiry 2.1 (2015): 5-32.

67 Wallace Zane, Journeys to the Spiritual Lands: The Natural History of a West Indian Religion (New York and Oxford: Oxford University Press, 1999), 4.

68 Zane, Journeys to the Spiritual Lands, 149.

69 Maarit Forde, 'The Spiritual Baptist Religion', Caribbean Quarterly: A Journal of Caribbean Culture 65.2 (2019), 216-17.

70 Diana Paton, 'Obeah Acts: Producing and Policing the Boundaries of Religion in the Caribbean', Small Axe 13.1 (2009), 13.

71 Zane, Journeys to the Spiritual Lands, 4, 20.

72 Zane, Journeys to the Spiritual Lands, 31.

73 Zane, Journeys to the Spiritual Lands, 99-100.

74 Zane, Journeys to the Spiritual Lands, 37.

75 Zane, Journeys to the Spiritual Lands, 40.

76 Zane, Journeys to the Spiritual Lands, 148.

77 Benjamin, 'On Ecstatic-Aesthetic Universality-in Zong!', 19.

78 Philip, Blank: Essays and Interviews, 13. See Lindon Barrett, Blackness and Value: Seeing Double (Cambridge: Cambridge University Press, 1999).

79 Philip, Zong!, 194.

80 Harry Garuba, 'On Animism, Modernity/Colonialism, and the African Order of Knowledge: Provisional Reflections', e-flux 36 (2012), n. p..

${ }^{81}$ For an excellent discussion of Zong! alongside Citizen, see Michael Leong, 'Conceptualisms in Crisis: The Fate of Late Conceptual Poetry’, Journal of Modern Literature 41.3 (2018): 109-131. 